\title{
Nanoparticle Drug Loading as a Design Parameter to Improve Docetaxel Pharmacokinetics and Efficacy
}

\author{
Kevin S. Chu, BS ${ }^{1}$, Allison N. Schorzman, $\mathrm{PhD}^{1}$, Mathew C. Finniss, MA ${ }^{3}$, Charles J. \\ Bowerman, PhD ${ }^{2,3}$, Lei Peng, BS ${ }^{1}$, J. Christopher Luft, PhD $^{2,3}$, Andrew Madden, Pharm $\mathbf{D}^{1}$, \\ Andrew Z. Wang, MD $3,4,6,8$, William C. Zamboni, Pharm D, PhD $\mathbf{D}^{1,3,5,6,7}$, and Joseph $\mathbf{M}$. \\ DeSimone, PhD ${ }^{1,2,3,5,6,7,8,9,10,11,{ }^{*}}$ \\ ${ }^{1}$ Department of Pharmaceutical Sciences, University of North Carolina at Chapel Hill \\ ${ }^{2}$ Department of Chemistry, University of North Carolina at Chapel Hill \\ ${ }^{3}$ Lineberger Comprehensive Cancer Center, University of North Carolina at Chapel Hill \\ ${ }^{4}$ Department of Radiation Oncology, University of North Carolina at Chapel Hill \\ ${ }^{5}$ Institute for Pharmacogenomics and Individualized Therapy, University of North Carolina at \\ Chapel Hill \\ ${ }^{6}$ Carolina Center of Cancer Nanotechnology Excellence, University of North Carolina at Chapel \\ Hill \\ ${ }^{7}$ Department of Pharmacology, Eshelman School of Pharmacy, University of North Carolina at \\ Chapel Hill \\ ${ }^{8}$ Institute for Nanomedicine, University of North Carolina at Chapel Hill \\ ${ }^{9}$ Institute for Advanced Materials, University of North Carolina at Chapel Hill \\ ${ }^{10}$ Department of Chemical and Biomolecular Engineering, North Carolina State University \\ ${ }^{11}$ Sloan-Kettering Institute for Cancer Research, Memorial Sloan-Kettering Cancer Center
}

\begin{abstract}
Nanoparticle (NP) drug loading is one of the key defining characteristics of a NP formulation. However, the effect of NP drug loading on therapeutic efficacy and pharmacokinetics has not been thoroughly evaluated. Herein, we characterized the efficacy, toxicity and pharmacokinetic properties of NP docetaxel formulations that have differential drug loading but are otherwise identical. Particle Replication in Non-wetting Templates (PRINT ${ }^{\circledR}$ ), a soft-lithography fabrication technique, was used to formulate NPs with identical size, shape and surface chemistry, but with variable docetaxel loading. The lower weight loading (9\%-NP) of docetaxel was found to have a superior pharmacokinetic profile and enhanced efficacy in a murine cancer model when compared to that of a higher docetaxel loading (20\%-NP). The 9\%-NP docetaxel increased plasma and tumor docetaxel exposure and reduced liver, spleen and lung exposure when compared to that of $20 \%$ NP docetaxel.
\end{abstract}

\footnotetext{
(C) 2013 Elsevier Ltd. All rights reserved.

"Corresponding Author. Department of Chemistry, The University of North Carolina at Chapel Hill, Campus Box \#3290, 257 Caudill, Chapel Hill, NC 27599-3290, (919) 962-2166 (phone), (919) 962-5467 (fax), desimone@ unc.edu.

Publisher's Disclaimer: This is a PDF file of an unedited manuscript that has been accepted for publication. As a service to our customers we are providing this early version of the manuscript. The manuscript will undergo copyediting, typesetting, and review of the resulting proof before it is published in its final citable form. Please note that during the production process errors may be discovered which could affect the content, and all legal disclaimers that apply to the journal pertain.
} 


\section{Introduction}

NP drug delivery has the potential to improve the effectiveness of small molecule chemotherapeutics. Though design parameters such as particle geometry [1-5] and surface chemistry [6] have been extensively studied to improve passive targeting, the effect of NP drug loading on therapeutic efficacy and pharmacokinetics has not been evaluated. NP drug loading is highly variable and often dependent upon the fabrication process. Polymeric formulations prepared by nanoprecipitation typically only achieve 1-2\% drug loading, but NPs prepared by emulsion/solvent evaporation have reported drug loadings as high as $14 \%$ [7,8]. Other commonly used nanocarriers that encapsulate chemotherapeutics such as liposomes, microemulsions and micelles also only achieve $\sim 10 \%$ drug loading [9-12].

Little is known about the the relationship between drug loading in NPs and the pharmacokinetics and efficacy of small molecules in vivo. To fill this knowledge gap, we aimed to compare particles with two different drug loadings. To accomplish this, we prepared biodegradable NPs containing docetaxel using the soft-lithography template-based fabrication approach known as PRINT ${ }^{\circledR}$. The PRINT ${ }^{\circledR}$ technology is capable of fabricating size and shape-specific particles with variable loadings of docetaxel [13]. In this report, the pharmacokinetics and efficacy of two identically sized and shaped NPs at $9 \%$ or $20 \%$ docetaxel loading were evaluated in vivo.

\section{Materials and Methods}

\subsection{Materials}

Poly(D,L-lactide-co-glycolide) (lactide:glycolide $85: 15,0.65 \mathrm{dL} / \mathrm{g}$ Inherent Viscosity at $\left.30^{\circ} \mathrm{C}\right)$ and Poly (L-lactide) $\left(0.5 \mathrm{dL} / \mathrm{g}\right.$ Inherent Viscosity at $\left.25^{\circ} \mathrm{C}\right)$ were purchased from Sigma-Aldrich. Chloroform and solvents (acetonitrile and water) for high performance liquid chromatography (HPLC) were purchased from Fisher Scientific. Docetaxel was purchased from LC Laboratories. Taxotere ${ }^{\circledR}$ (free docetaxel) was purchased from the University of North Carolina at Chapel Hill hospital pharmacy for research purposes. Poly(ethylene terephthalate) (PET) sheets (6" width) were purchased from KRS plastics. Fluorocur $^{\circledR}$, diameter $(\mathrm{d})=80 \mathrm{~nm}$; height $(\mathrm{h})=320 \mathrm{~nm}$; $(80 \times 320)$ prefabricated molds and 2,000 g/mol polyvinyl alcohol $(\mathrm{PVOH})$ coated PET sheets were provided by Liquidia Technologies.

\subsection{Particle Fabrication and Characterization}

Particles were fabricated with solutions of PLA, PLGA and docetaxel dissolved in chloroform. The ratio of PLA:PLGA was 30:70. Two particle formulations at different weight percents of docetaxel were prepared. The particle fabrication and characterization follows previously published methods [13].

\subsection{A549 human alveolar adenocarcinoma tumor xenografts}

This study was done with an approved protocol with the University of North Carolina at Chapel Hill's Institutional Animal Care and Use Committee. All animals used were treated humanely. A549 cells were acquired from ATCC. Female nude mice, aged 4-6 weeks and $\sim 20$ grams in body weight, were ordered from University of North Carolina at Chapel Hill's animal core. The mice were acclimated for 1 week prior to tumor cell injection. Cells $\left(5.0 \times 10^{6}\right.$ cells in $200 \mu \mathrm{L} 1 \times$ PBS $)$ were injected subcutaneously into the right flank of each mouse. Tumor volume was calculated using the formula: tumor volume $\left(\mathrm{mm}^{3}\right)=\left(w^{2} \times I\right) / 2$, where $W=$ width and $I=$ length in $\mathrm{mm}$ of the tumor. 
For the orthotopic lung cancer model, A549-luciferase-c8 cells were harvested and suspended in phosphate buffered saline and BD Matrigel Basement Membrane Matrix at a ratio of $4: 1$. Cells $\left(5.0 \times 10^{6}\right.$ cells in $50 \mu \mathrm{L} 1 \times$ PBS:Matrigel) were injected directly into the left lung parenchyma [14].

\subsection{Pharmacokinetic study}

40 days after cells were inoculated subcutaneously when all mice had a median tumor volume of $150 \mathrm{~mm}^{3}$, mice were pair matched according to tumor volume. All mice received $10 \mathrm{mg} / \mathrm{kg}$ docetaxel via a single tail vein injection. Formulations were diluted to $1 \mathrm{mg} / \mathrm{mL}$ of docetaxel with normal saline and mice were dosed at $10 \mu \mathrm{L}$ of solution per gram of body weight. Mice ( $\mathrm{N}=3$ per time point per arm) were sacrificed at 0.083, 1, 6, 24, 72, and 168 hours after dosing. Blood ( 1 $\mathrm{mL}$ ) was collected via terminal cardiac puncture using K3EDTA as an anticoagulant under $\mathrm{CO}_{2}$ anesthesia and processed for plasma by centrifugation $(1,500 \times g$ for $5 \mathrm{~min})$. Plasma and tissues were placed in cryopreservation vials and preserved by snap freezing using liquid nitrogen, and stored at $-80^{\circ} \mathrm{C}$ until analysis. Tissues were homogenized in water (1:3, tissue:water) prior to analysis [15].

\subsection{Protein precipitation}

Docetaxel and paclitaxel stock solutions $(1 \mathrm{mg} / \mathrm{mL})$ were stored in methanol at $-20^{\circ} \mathrm{C}$. The standard curve concentrations of docetaxel in matrix were 1, 3, 5, 10,30, 50, 100, 300, 500, 1000,3000 and $5000 \mathrm{ng} / \mathrm{mL}$ and the quality control (QC) concentrations were 4, 40, 400, and $4000 \mathrm{ng} / \mathrm{mL}$. The matrix for the standard curve and QCs consisted of control mouse plasma for all plasma samples, or control plasma mixed 1:1 with a control tissue homogenate for the tissue being analyzed. A liver/plasma surrogate matrix was used for tumor samples. All tumor and tissue samples were mixed 1:1 with control plasma prior to analysis. Docetaxel was dissolved from the NP and extracted from $50 \mu \mathrm{L}$ of sample by protein precipitation with $200 \mu \mathrm{L}$ acetonitrile/ $0.1 \%$ formic acid containing $20 \mathrm{ng} / \mathrm{mL}$ paclitaxel internal standard. Samples were vortexed for 5 minutes and centrifuged at 3,000 $\times$ $g$ for 10 minutes at $4^{\circ} \mathrm{C} .170 \mu \mathrm{L}$ supernatant was transferred to a clean $1.5 \mathrm{~mL}$ tube, lyophilized under nitrogen and reconstituted in $60 \mu \mathrm{L}$ of $\mathrm{MeOH} / 0.1 \%$ formic acid. $50 \mu \mathrm{L}$ of

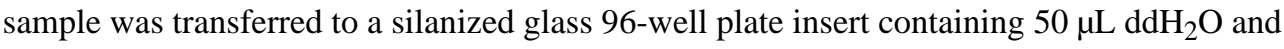
$10 \mu \mathrm{L}$ of sample injected for LC-MS/MS analysis.

\subsection{LC-MS/MS}

Docetaxel and paclitaxel (internal standard) were separated on a Waters XSelect CSH Phenyl-Hexyl column $(2.1 \times 50 \mathrm{~mm}, 130 \AA$ pore size, $5 \mu \mathrm{m}$ particle size $)$ using a gradient mobile phase consisting of $0.1 \%$ formic acid in water (mobile phase $\mathrm{A}$ ) and $0.1 \%$ formic acid and 10\% isopropanol in acetonitrile (mobile phase B) on a Shimadzu LC-20AD liquid chromatography system. The flow rate was $0.33 \mathrm{~mL} / \mathrm{min}$ and the total run time was 6 minutes. The compounds were measured using a Thermo TSQ Ultra triple quadrupole mass spectrometer equipped with a heated electrospray ionization source in the positive ion mode. The discharge current was held at $3.7 \mathrm{kV}$ and the vaporizer temperature at $225^{\circ} \mathrm{C}$. Docetaxel and paclitaxel were detected by selected-reaction monitoring (SRM) using the transitions $808 \rightarrow 527$ and $854 \rightarrow 286$, respectively. Calibration curves were fit using linear regression with $1 / \mathrm{X}^{2}$ weighting in Xcalibur® v. 2.0 (Thermo Fisher Scientific, Waltham, MA).

\subsection{Maximum Tolerated Dose Determination}

The maximum tolerated doses (MTD) of free docetaxel and the docetaxel NPs were determined for a weekly $\times 6$ schedule in female nude mice. At time of the first dose, mice were 6 weeks in age. Mice were monitored for body weight loss and overall health. Mice were sacrificed if body weight loss exceeded $20 \%$ or if they exhibited excessive signs of 
toxicity. The MTD was selected as the dose that did not cause excessive toxicity that required a mouse to be sacrificed or body weight loss greater than $10 \%$.

\subsection{Tumor Growth Inhibition Studies}

16 days after cell inoculation to the lung, mice were randomized into four groups $(\mathrm{N}=8$ mice per group for mice receiving free docetaxel, $9 \%-\mathrm{NP}$, or 20\%-NP and $\mathrm{N}=6$ mice per group for mice receiving saline). Mice were dosed via tail vein at $10 \mu \mathrm{L}$ per gram body weight. Mice either received saline, $10 \mathrm{mg} / \mathrm{kg}$ docetaxel for free docetaxel, or $15 \mathrm{mg} / \mathrm{kg}$ docetaxel for mice receiving 9\%-NP and 20\%-NP. Mice were sacrificed when they had excessive body weight loss or excessive toxicity. Mice were imaged once a week using an IVIS Lumina Imager. Prior to imaging, mice were injected $10 \mu \mathrm{L}$ per gram body weight with a 15 $\mathrm{mg} / \mathrm{mL}$ luciferase solution. Mice were anesthetized with isoflurane prior to imaging.

\subsection{Hematological Tests}

$50 \mu \mathrm{L}$ of blood was collected into EDTA-coated tubes by submandibular bleeding the day of the first injection, 4 days after the $1^{\text {st }}$ injection and 4 days after the $6^{\text {th }}$ injection. Blood was analyzed for complete blood counts with differential using Heska's blood counter.

\subsection{Statistical and Pharmacokinetic Analysis}

GraphPad Prism was used to perform statistical tests. Student's t-test was utilized when only two groups were compared. One way analysis of variance (ANOVA) followed by a modified t-test for multiple comparisons was used when more than 2 groups were compared. Survival data was analyzed by Log-Rank test. Pharmacokinetic data was analyzed by noncompartmental methods using WinNonlin Professional Edition version 5.2.1 (Pharsight Corp, Cary, NC). The area under the concentration versus time curve from 0 to $t\left(\mathrm{AUC}_{0-\mathrm{t}}\right)$ was calculated using the linear up/log down rule. Volume of distribution $\left(\mathrm{V}_{\mathrm{d}}\right)$ and clearance $(\mathrm{CL})$ were calculated using standard equations. The maximum concentration $\left(\mathrm{C}_{\max }\right)$ and time of $\mathrm{C}_{\max }\left(\mathrm{T}_{\max }\right)$ were determined by visual inspection of the concentration versus time curve data.

\section{Results}

\subsection{Particle Characteristics}

To achieve different loadings, PLA/PLGA particles were fabricated with different amounts of docetaxel. Despite having different drug loadings of docetaxel, all other particle characteristics were identical as shown in Table 1 . As measured by dynamic light scattering (DLS), both sets of $80 \times 320 \mathrm{NPs}$ were $216 \mathrm{~nm}$ in hydrodynamic diameter with polydispersity indices (PDI) of less than 0.1. The total percent drug released after 24 hours was similar for both NPs (Figure 1), but the 20\%-NP had slightly faster burst release within the first 6 hours compared to the $9 \%-\mathrm{NP}$.

\subsection{Pharmacokinetics}

The pharmacokinetic parameters and profiles of the 9\%-NP and 20\%-NP are shown in Table 2 and Figure 1. The sum total (encapsulated and released) docetaxel was measured and is reported.

Docetaxel plasma exposure as measured by AUC of the concentration - time curve was 1.15-fold higher for mice receiving 9\%-NPs compared to 20\%-NPs. The $\mathrm{V}_{\mathrm{d}}$ and CL of docetaxel was lower for the $9 \%$-NP group. The $\mathrm{C}_{\max }$ observed in both NP groups were not statistically significant and $\mathrm{T}_{1 / 2}$ were similar. Docetaxel was not detectable at 168 hours post injection for both NPs. 
Large differences in tissue docetaxel accumulation were observed between both NP groups. Mice receiving 9\%-NP had 1.39-fold higher tumor docetaxel exposure than mice receiving 20\%-NP. Maximum tumor docetaxel concentrations were not statistically significant between the two NP groups, but the $\mathrm{C}_{\max }$ was observed at different times. For the 20\%-NP group, the $\mathrm{C}_{\max }$ was observed immediately after injection at 5 minutes, where as the $\mathrm{C}_{\max }$ of the $9 \%$-NP group was observed at 24 hours post injection.

Liver exposure of the 20\%-NP group was $~ 1.40$-fold higher than the 9\%-NP group, but the observed $\mathrm{C}_{\max }$ of both groups were not statistically significant. At 6 and 72 hours post injection, the docetaxel concentration of the 20\%-NP group was statistically higher than the 9\%-NP group: $\mathrm{P}=0.02$ at 6 hours $(12,468 \pm 1,512$ versus $8,025 \pm 2,214)$ and $\mathrm{P}=0.05$ at 72 hours $(10,464 \pm 2,828$ versus $5,765 \pm 525)$. Spleen exposure of the $20 \%$-NP group was $\sim 1.31$-fold higher than the $9 \%$-NP group. Spleen docetaxel concentration was statistically higher for the 20\%-NP group at 1 hour post injection ( $\mathrm{P}=0.03,73,061 \pm 10,855$ versus $31,117 \pm 19,382$ ). Lung exposure of the $20 \%$-NP group was $~ 1.56$-fold higher than the $9 \%$ NP group.

\subsection{Maximum Tolerated Dose}

The maximum tolerated dose of free docetaxel and the 20\%-NP was determined in female non tumor bearing nude mice following a weekly dosing schedule for 6 weeks. The MTD of free docetaxel was expected to be $13-20 \mathrm{mg} / \mathrm{kg}[16,17]$. Poly(L-lactide) NPs containing taxanes have been shown to have a higher MTD than the free taxane formulation [18]. Thus, $20 \mathrm{mg} / \mathrm{kg}$ was selected as the starting dose for the free docetaxel group and $30 \mathrm{mg} / \mathrm{kg}$ was selected as the starting dose for the docetaxel NP group.

The MTD of free docetaxel in female non tumor bearing mice was found to be $20 \mathrm{mg} / \mathrm{kg}$ weekly for 6 weeks. 2 mice were sacrificed within the $27 \mathrm{mg} / \mathrm{kg}$ arm and 1 mouse was sacrificed in the $35 \mathrm{mg} / \mathrm{kg}$ arm for excessive toxicity. Additionally, mice in both the $27 \mathrm{mg}$ / $\mathrm{kg}$ and $35 \mathrm{mg} / \mathrm{kg}$ free docetaxel arms had body weight loss that surpassed 10\%. The MTD of the docetaxel NPs was found to be $30 \mathrm{mg} / \mathrm{kg}$ weekly for 6 weeks. At $37.5 \mathrm{mg} / \mathrm{kg}, 2$ mice were sacrificed after the $6^{\text {th }}$ dose and at $45 \mathrm{mg} / \mathrm{kg}$, all mice were sacrificed after the $6^{\text {th }}$ dose. Also, the mean body weight loss of mice receiving $37.5 \mathrm{mg} / \mathrm{kg}$ and $45 \mathrm{mg} / \mathrm{kg}$ exceeded $10 \%$. The mean body weights and survival are shown in Figure 2 and Table 3, respectively.

\subsection{White blood cell counts}

White blood cell counts (WBC) were measured one week before the $1^{\text {st }}$ injection and 4 days after the $1^{\text {st }}$ and $6^{\text {th }}$ injection of free docetaxel or docetaxel NPs and are reported in Table 4. WBC counts of all groups were not statistically significant 1 week before the $1^{\text {st }}$ dose as measured by one-way ANOVA. Mice receiving $9 \%$-NP or $20 \%$-NP did not have statistically significant differences in their WBC 4 days after the $1^{\text {st }}$ and $6^{\text {th }}$ dose.

\subsection{Tumor Growth Inhibition}

Efficacy was evaluated in an orthotopic tumor model of non small cell lung cancer. Because MTDs of the docetaxel formulations were determined in non tumor bearing mice, the MTDs may be lower in mice with orthotopic lung xenografts. To avoid toxicity attributed to docetaxel, mice received doses that were half of the MTD in non-tumor bearing mice. Survival analysis by Kaplan-Meier estimate demonstrated that $9 \%$-NP was the superior treatment $(\mathrm{P}=0.03$ compared to free docetaxel). Mice that received $9 \%$-NPs or $20 \%$-NPs had minimal or no tumor growth even 150 days post cell implantation (Figure 3). 6/6 mice in the saline group and 6/8 mice in the free docetaxel treatment groups had tumor growth that required mice to be sacrificed. 


\section{Discussion}

We studied drug loading as a parameter that affects the therapeutic efficacy, pharmacokinetics and toxicity of docetaxel. Most NP fabrication techniques are limited to drug loadings of $\sim 10 \%$. PRINT ${ }^{\circledR}$ has previously demonstrated the ability to make NPs with variable drug loadings. Therefore, we prepared one NP formulation to match the loading of a taxane NP that is currently in clinical development [7] and for comparison, a second NP formulation was prepared that targeted to double the loading to $20 \%$.

There are multiple benefits of preparing NP formulations with higher drug loading. Higher drug loading is preferable because less non active excipients are used to produce the same quantity of active pharmaceutical ingredient (API) in the NP formulation. At a higher drug loading, a lower number of particles need to be manufactured to deliver an equivalent dose of API. Reducing the number of NPs that need to be manufactured can reduce manufacturing and processing time, raw material usage, and energy needs as many NP manufacturing processes require input of mechanical energy.

From a manufacturing viewpoint, achieving the highest drug loading possible is desired, but we have demonstrated that there are benefits in using NPs with lower drug loading. Mice receiving the 9\%-NPs had more favorable pharmacokinetic profile compared to mice receiving 20\%-NP. Less liver and spleen accumulation as measured by AUC was observed in mice receiving 9\%-NPs compared to the 20\%-NPs. Though all mice in the NP arms received $15 \mathrm{mg} / \mathrm{kg}$ of docetaxel, the total dose of particles received in the 9\%-NP group was $\sim 109 \mathrm{mg} / \mathrm{kg}$ compared to only $50 \mathrm{mg} / \mathrm{kg}$ in the $20 \%-\mathrm{NP}$ group. The higher particle dose associated with the 9\%-NP formulation may have saturated the mononuclear phagocyte system (MPS) of the liver and spleen. Reduced docetaxel accumulation in the liver and spleen of mice receiving 9\%-NP may account for the increased plasma and tumor docetaxel exposure relative to the 20\%-NP group. Tumor docetaxel concentration increased during the first 24 hours post injection for the 9\%-NP group where as the 20\%-NP group reached docetaxel $\mathrm{C}_{\max }$ immediately after injection.

Multiple preclinical studies have evaluated the effect of concurrently or pre-administering NPs on the pharmacokinetics of a second dose of NPs [19-24]. These studies demonstrated that NP clearance could be limited by the saturation of the mononuclear phagocyte system (MPS), most notably in the liver by NPs. Additionally, differences in MPS saturation were observed between liposomes and polymeric particles of different compositions and surface chemistries $[21,22,24]$. Similarly, increasing the number of particles injected may saturate the MPS. Future studies are planned to investigate this phenomenon in more depth. Assays to identify the drug distribution in the cells of the MPS after administration of docetaxel NPs to mice are currently being developed.

\section{Conclusion}

In this report, the dependence of small molecule pharmacokinetics on drug loading in a NP was demonstrated in vivo. Mice that received a 9\%-NP formulation compared to a $20 \%$-NP formulation had $\sim 24-36 \%$ less docetaxel exposure in organs of the MPS, and as a result, had increased plasma and tumor docetaxel exposure of $\sim 16 \%$ and $39 \%$, respectively. Saturation of the MPS due to an increased particle dose may be responsible for the observed differences in docetaxel exposure. Particle dose and drug loading are critical formulation parameters used to help maximize the pharmacokinetics of small molecules. With maximized docetaxel plasma and tumor exposure, an increase in therapeutic efficacy of the 9\%-NP was observed in an orthotopic xenograft mouse model. As variations in drug loading may alter in vivo performance, these findings highlight drug loading as an important 
consideration in the manufacturing of NPs. Achieving consistency in the particle manufacturing process may ensure that particle batches not only have bioequivalence as measured by in vitro assays, but also maintain bioequivalence in vivo.

\section{Acknowledgments}

This work was supported by the Carolina Center for Nanotechnology Excellence (U54-CA151652 and U54CA119343), University Cancer Research Fund, and Liquidia Technologies, Inc. The authors acknowledge Charlene Ross of the Animal Studies Core at the University of North Carolina at Chapel Hill.

\section{References}

1. Tang L, Fan FM, Borst LB, Cheng J. Synthesis and biological response of size-specific, monodisperse drug-silica nanoconjugates. ACS Nano. 2003; 6:3954-3966. [PubMed: 22494403]

2. Chu KS, Hasan W, Rawal S, Walsh MD, Enlow EM, Luft JC, et al. Plasma, tumor and tissue pharmacokinetics of Docetaxel delivered via nanoparticles of different sizes and shapes in mice bearing SKOV-3 human ovarian carcinoma xenograft. Nanomedicine. 2013; 9:686-693. [PubMed: 23219874]

3. Chauhan VP, Popović Z, Chen O, Cui J, Fukumura D, Bawendi MG, et al. Fluorescent nanorods and nanospheres for real-time in vivo probing of nanoparticle shape-dependent tumor penetration. Angew Chem Int Ed Engl. 2011; 50:11417-11420. [PubMed: 22113800]

4. Cabral H, Matsumoto Y, Mizuno K, Chen Q, Murakami M, Kimura M, et al. Accumulation of sub-100 nm polymeric micelles in poorly permeable tumours depends on size. Nat Nanotechnol. 2011; 6:815-823. [PubMed: 22020122]

5. Smith BR, Kempen P, Bouley D, Xu A, Liu Z, Melosh N, et al. Shape matters: intravital microscopy reveals surprising geometrical dependence for nanoparticles in tumor models of extravasation. Nano Lett. 2012; 12:3369-3377. [PubMed: 22650417]

6. Campbell RB, Fukumura D, Brown EB, Mazzola LM, Izumi Y, Jain RK, et al. Cationic charge determines the distribution of liposomes between the vascular and extravascular compartments of tumors. Cancer Res. 2002; 62:6831-6836. [PubMed: 12460895]

7. Hrkach J, Von Hoff D, Ali MM, Andrianova E, Auer J, Campbell T, et al. Preclinical development and clinical translation of a PSMA-targeted docetaxel nanoparticle with a differentiated pharmacological profile. Sci Transl Med. 2012; 4:128ra39.

8. Cheng J, Teply BA, Sherifi I, Sung J, Luther G, Gu FX, et al. Formulation of functionalized PLGAPEG nanoparticles for in vivo targeted drug delivery. Biomaterials. 2007; 28:869-876. [PubMed: 17055572]

9. Dong X, Mattingly CA, Tseng MT, Cho MJ, Liu Y, Adams VR, et al. Doxorubicin and paclitaxelloaded lipid-based nanoparticles overcome multidrug resistance by inhibiting P-glycoprotein and depleting ATP. Cancer Res. 2009; 69:3918-3926. [PubMed: 19383919]

10. Tardi PG, Gallagher RC, Johnstone S, Harasym N, Webb M, Bally MB, et al. Coencapsulation of irinotecan and floxuridine into low cholesterol-containing liposomes that coordinate drug release in vivo. Biochim Biophys Acta. 2007; 1768:678-687. [PubMed: 17208196]

11. Dicko A, Kwak S, Frazier AA, Mayer LD, Liboiron BD. Biophysical characterization of a liposomal formulation of cytarabine and daunorubicin. Int J Pharm. 2010; 391:248-259. [PubMed: 20156541]

12. Yu Y, He Y, Xu B, He Z, Zhang Y, Chen Y, et al. Self-assembled methoxy poly(ethylene glycol)cholesterol micelles for hydrophobic drug delivery. J Pharm Sci. 2012; 102:1-9.

13. Enlow EM, Luft JC, Napier ME, DeSimone JM. Potent engineered PLGA nanoparticles by virtue of exceptionally high chemotherapeutic loadings. Nano Lett. 2011; 11:808-813. [PubMed: 21265552]

14. Peng L, Feng L, Benhabbour SR, Mumper RJ. Development of a Novel Orthotopic Non-small Cell Lung Cancer Model and Therapeutic Benefit of 2'-(2-bromohexadecanoyl)-Docetaxel Conjugate Nanoparticles. Submitted.

15. Walsh MD, Hanna SK, Sen J, Rawal S, Cabral CB, Yurkovetskiy AV, et al. Pharmacokinetics and antitumor efficacy of XMT-1001, a novel, polymeric topoisomerase I inhibitor, in mice bearing 
HT-29 human colon carcinoma xenografts. Clin Cancer Res. 2012; 18:2591-2602. [PubMed: 22392910]

16. Desai N, Trieu V, Yao Z, Louie L, Ci S, Yang A, et al. Increased antitumor activity, intratumor paclitaxel concentrations, and endothelial cell transport of cremophor-free, albumin-bound paclitaxel, ABI-007, compared with cremophor-based paclitaxel. Clin Cancer Res. 2006; 12:13171324. [PubMed: 16489089]

17. Desai NP, Trieu V, Hwang LY, Wu R, Soon-Shiong P, Gradishar WJ. Improved effectiveness of nanoparticle albumin-bound (nab) paclitaxel versus polysorbate-based docetaxel in multiple xenografts as a function of HER2 and SPARC status. Anticancer Drugs. 2008; 19:899-909. [PubMed: 18766004]

18. Kim SC, Kim DW, Shim YH, Bang JS, Oh HS, Wan Kim S, et al. In vivo evaluation of polymeric micellar paclitaxel formulation: toxicity and efficacy. J Control Release. 2001; 72:191-202. [PubMed: 11389998]

19. Dave J, Patel HM. Differentiation in hepatic and splenic phagocytic activity during reticuloendothelial blockade with cholesterol-free and cholesterol-rich liposomes. Biochim Biophys Acta. 1986; 888:184-190. [PubMed: 3741891]

20. Gabizon A, Tzemach D, Mak L, Bronstein M, Horowitz AT. Dose dependency of pharmacokinetics and therapeutic efficacy of pegylated liposomal doxorubicin (DOXIL) in murine models. J Drug Target. 2002; 10:539-548. [PubMed: 12683721]

21. Panagi Z, Beletsi A, Evangelatos G, Livaniou E, Ithakissios DS, Avgoustakis K. Effect of dose on the biodistribution and pharmacokinetics of PLGA and PLGA-mPEG nanoparticles. Int J Pharm. 2001; 221:143-152. [PubMed: 11397575]

22. Patel HM, Tuzel NS, Ryman BE. Inhibitory effect of cholesterol on the uptake of liposomes by liver and spleen. Biochim Biophys Acta. 1983; 761:142-151. [PubMed: 6652107]

23. Allen TM, Hansen C. Pharmacokinetics of stealth versus conventional liposomes: effect of dose. Biochim Biophys Acta. 1991; 1068:133-141. [PubMed: 1911826]

24. Souhami RL, Patel HM, Ryman BE. The effect of reticuloendothelial blockade on the blood clearance and tissue distribution of liposomes. Biochim Biophys Acta. 1981; 674:354-371. [PubMed: 6165399] 
A

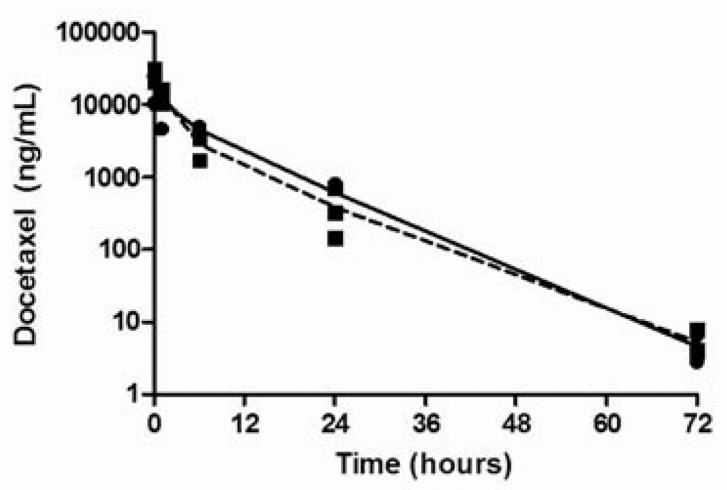

C

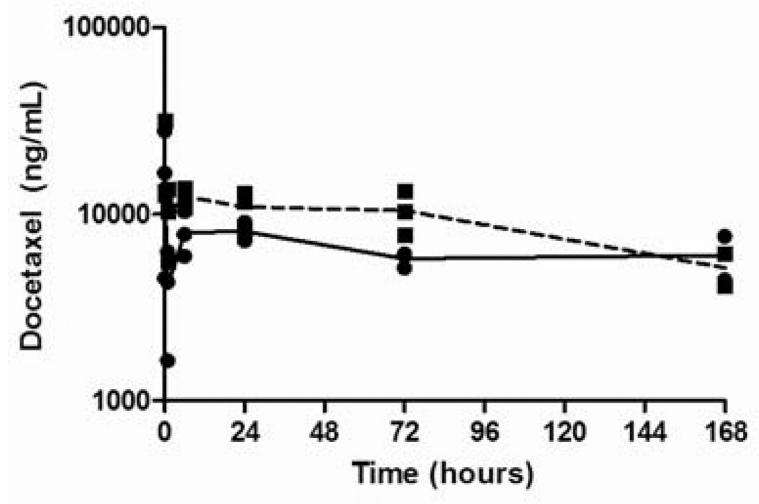

E

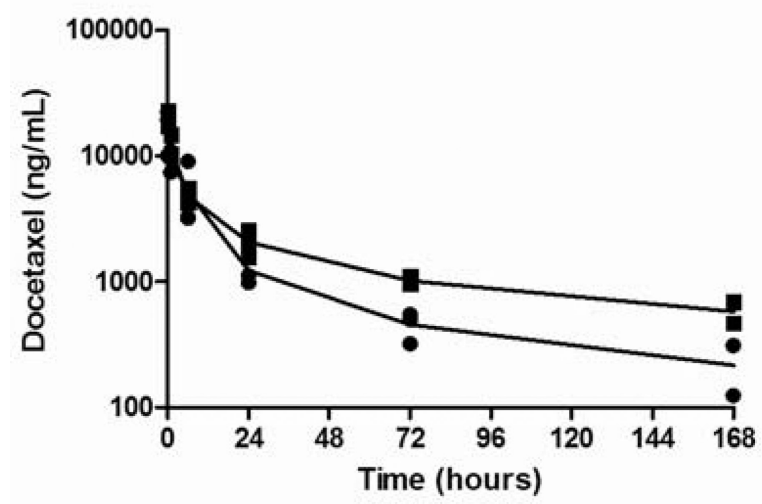

B

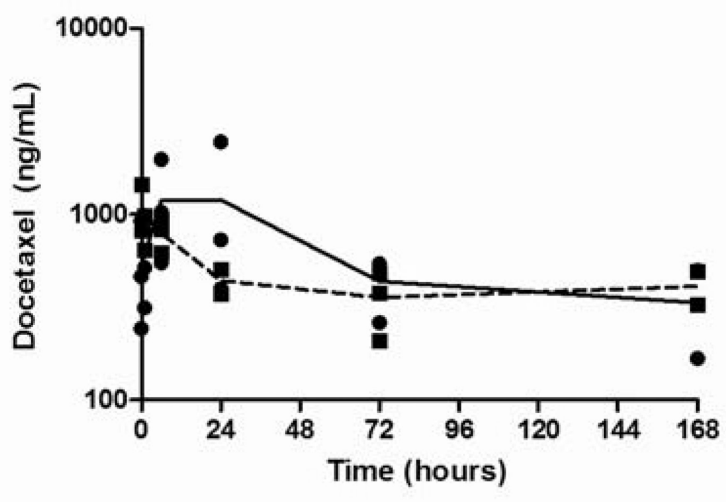

D

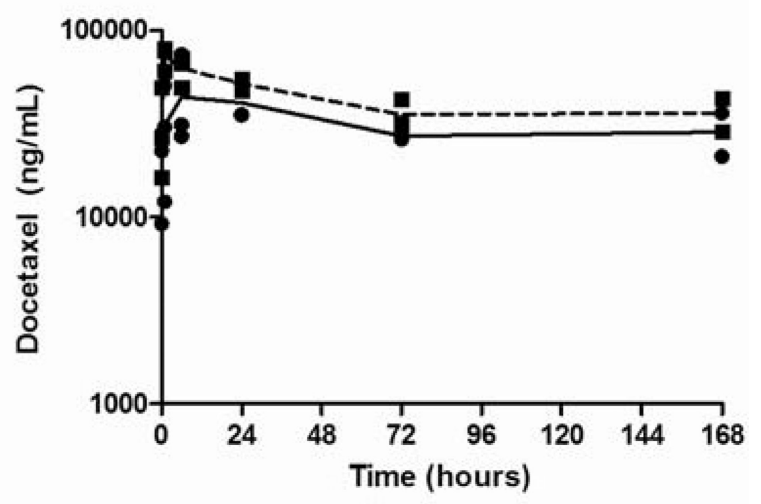

$\mathbf{F}$

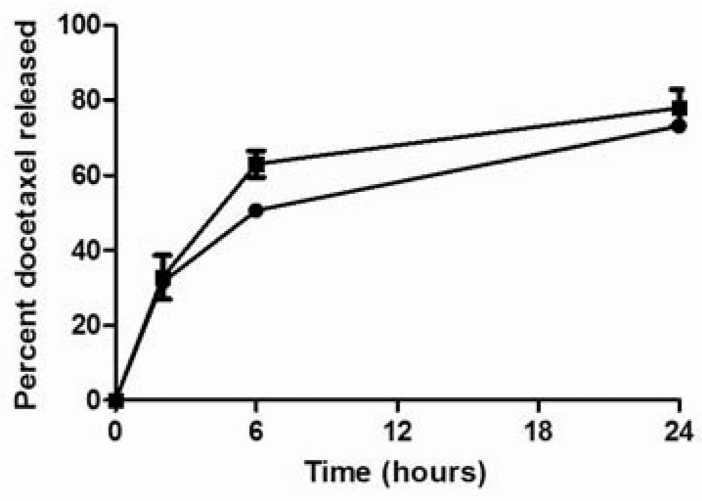

Figure 1.

Pharmacokinetic profiles of (A) Plasma, (B) Tumor, (C) Liver, (D) Spleen and (E) Lung. (F) In vitro release kinetics of $9 \%-\mathrm{NP}($ and $20 \%-\mathrm{NP}(\mathbf{D})$. Each replicate is shown and the lines are connected by the mean of three replicates. 

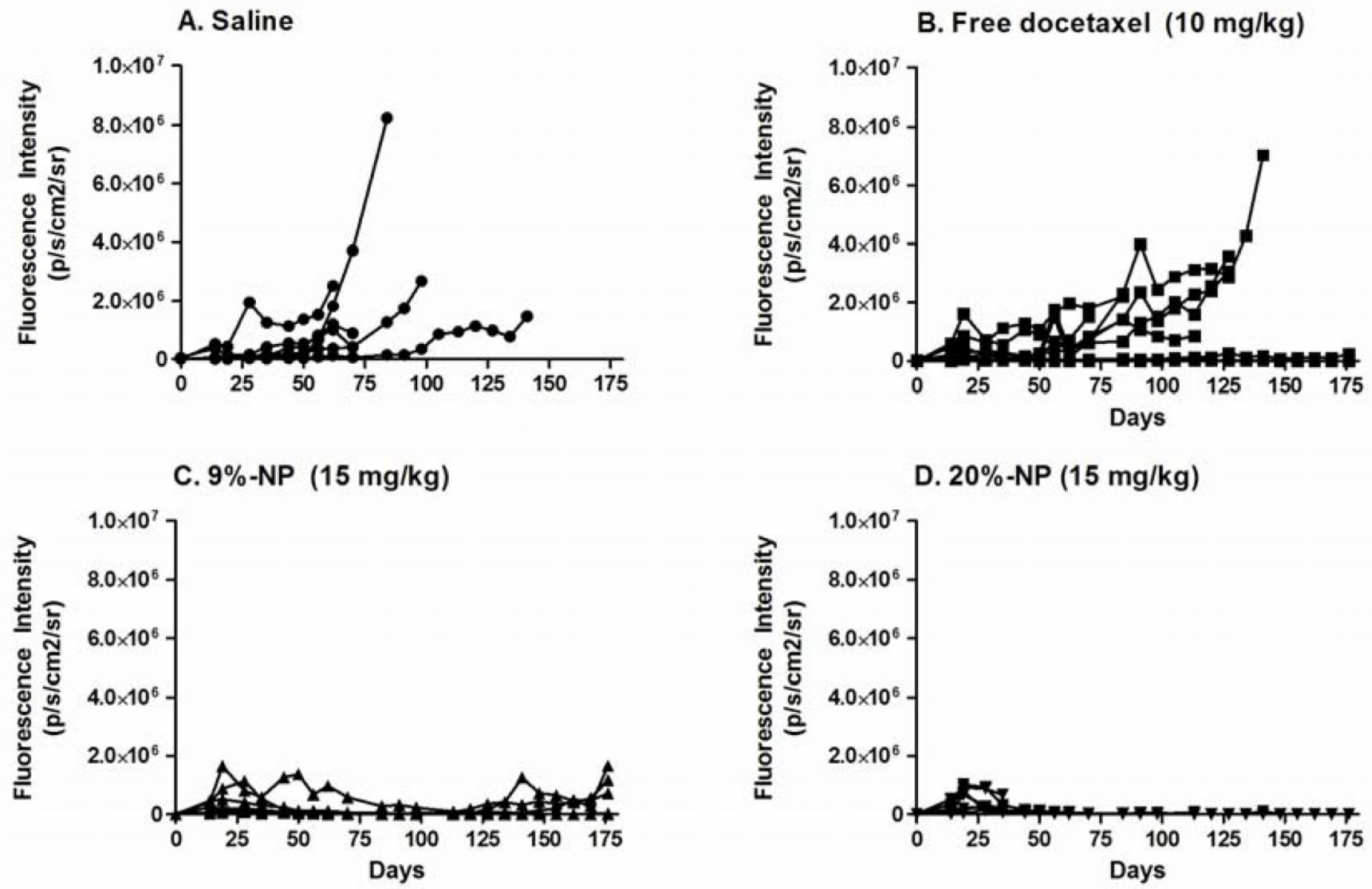

\section{E. Kaplan-Meier}

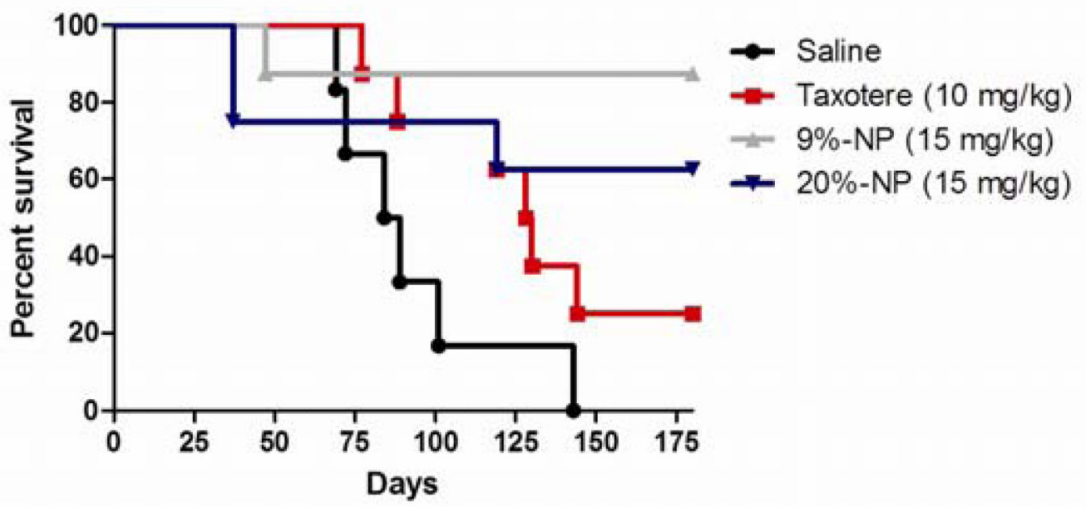

Figure 2.

Mean body weight of mice in MTD study. Dose 1 was on Day 0 . 


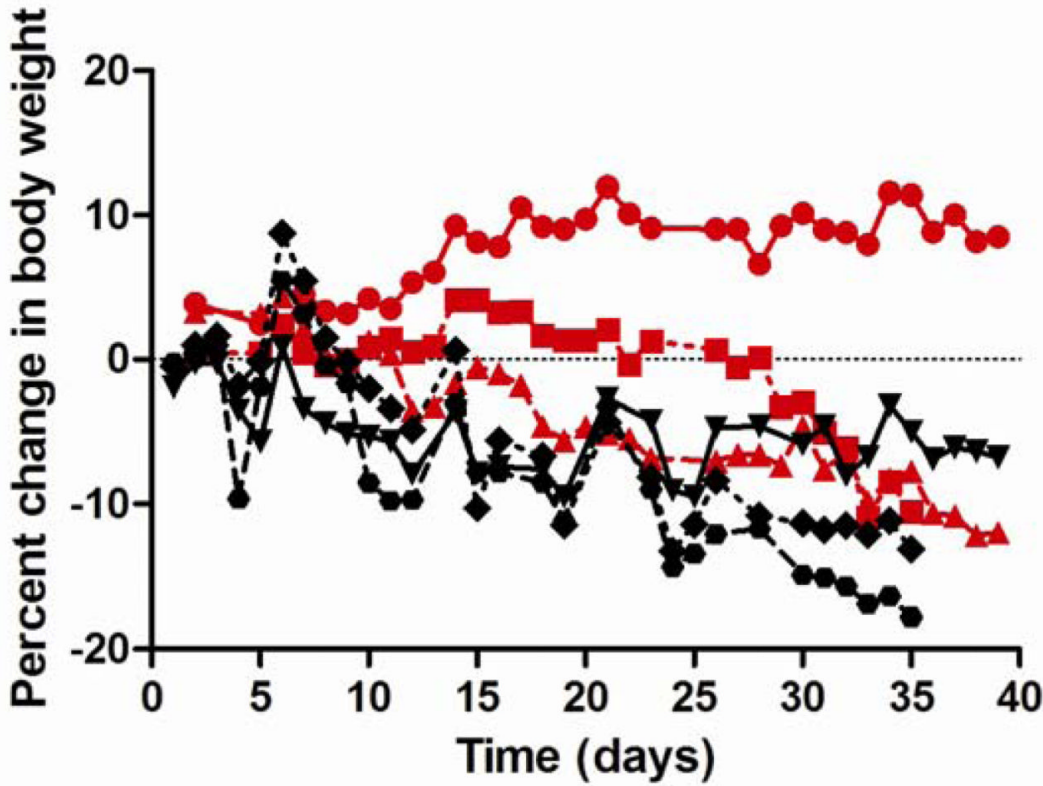

$\rightarrow$ Free docetaxel $(20 \mathrm{mg} / \mathrm{kg})$

- 흐- Free docetaxel $(27 \mathrm{mg} / \mathrm{kg})$

-ז. Free docetaxel $(35 \mathrm{mg} / \mathrm{kg})$

$\rightarrow$ Docetaxel NP $(30 \mathrm{mg} / \mathrm{kg}$ )

- - Docetaxel NP $(37.5 \mathrm{mg} / \mathrm{kg})$

$\rightarrow$ Docetaxel NP (45 mg/kg)

Figure 3.

Tumor growth rates and Kaplan-Meier curve of mice with A549 orthotopic lung xenografts. 
Table 1

Particle Characteristics of 9\%-NP and 20\%-NP.

\begin{tabular}{|l|l|l|l|l|}
\hline Formulation & Size $(\mathbf{n m})$ & PDI & Zeta Potential $(\mathbf{m V})$ & Weight percent docetaxel \\
\hline $20 \%-\mathrm{NP}$ & $216 \pm 2$ & $0.07 \pm 0.01$ & $-3.36 \pm 0.16$ & $20.1 \pm 1.5$ \\
\hline $9 \%-\mathrm{NP}$ & $216 \pm 1$ & $0.09 \pm 0.03$ & $-3.11 \pm 0.28$ & $9.2 \pm 1.6$ \\
\hline
\end{tabular}


Table 2

Docetaxel pharmacokinetic parameters of $9 \%$-NP and $20 \%$-NP

\begin{tabular}{|c|c|c|c|}
\hline \multirow[t]{2}{*}{ Specimen } & \multirow[t]{2}{*}{ Parameter } & \multicolumn{2}{|c|}{ Formulation } \\
\hline & & $9 \%-N P$ & $20 \%-\mathrm{NP}$ \\
\hline \multirow[t]{5}{*}{ Plasma } & $\mathrm{AUC}(\mathrm{ng} / \mathrm{mL} \mathrm{h})$ & $95,692(0-72 \mathrm{~h})$ & $82,743(0-72 \mathrm{~h})$ \\
\hline & $\mathrm{C}_{\max }(\mathrm{ng} / \mathrm{mL})$ & $19,583 \pm 7,997$ & $26,753 \pm 5,603$ \\
\hline & $\mathrm{CL}(\mathrm{mL} / \mathrm{h} / \mathrm{kg})$ & 105 & 121 \\
\hline & $\mathrm{Vd}(\mathrm{mL} / \mathrm{kg})$ & 943 & 1278 \\
\hline & $\mathrm{T}_{1 / 2}(\mathrm{~h})$ & 6.6 & 7.4 \\
\hline \multirow[t]{2}{*}{ Tumor } & $\mathrm{AUC}(\mathrm{ng} / \mathrm{mL} \mathrm{h})$ & $99,586(0-168 \mathrm{~h})$ & $71,848(0-168 \mathrm{~h})$ \\
\hline & $\mathrm{C}_{\max }(\mathrm{ng} / \mathrm{mL})$ & $1,199 \pm 1,115$ & $1038 \pm 366$ \\
\hline \multirow[t]{2}{*}{ Liver } & AUC (ng/mL h) & $1,080,179(0-168 \mathrm{~h})$ & $1,513,225(0-168 \mathrm{~h})$ \\
\hline & $\mathrm{C}_{\max }(\mathrm{ng} / \mathrm{mL})$ & $16,359 \pm 11,681$ & $19,274 \pm 10,838$ \\
\hline \multirow[t]{2}{*}{ Spleen } & AUC (ng/mL h) & $5,282,385(0-168 \mathrm{~h})$ & $6,934,196(0-168 \mathrm{~h})$ \\
\hline & $\mathrm{C}_{\max }(\mathrm{ng} / \mathrm{mL})$ & $44,294 \pm 26,239$ & $73,061 \pm 10,855$ \\
\hline \multirow[t]{2}{*}{ Lung } & $\mathrm{AUC}(\mathrm{ng} / \mathrm{mL} \mathrm{h})$ & $165,962(0-168 \mathrm{~h})$ & $258,766(0-168 \mathrm{~h})$ \\
\hline & $\mathrm{C}_{\max }(\mathrm{ng} / \mathrm{mL})$ & $17,218 \pm 6,347$ & $20,200 \pm 2,861$ \\
\hline
\end{tabular}


Table 3

Survival at each dose level for MTD study.

\begin{tabular}{|l|l|l|}
\hline & \multicolumn{2}{|c|}{ Formulation } \\
\hline Dose $(\mathbf{m g} / \mathbf{k g})$ & free docetaxel & Docetaxel NP \\
\hline 20 & $3 / 3$ & - \\
\hline 27 & $1 / 3$ & - \\
\hline 30 & - & $3 / 3$ \\
\hline 35 & $2 / 3$ & - \\
\hline 37 & - & $1 / 3$ \\
\hline 45 & - & $0 / 3$ \\
\hline
\end{tabular}


Table 4

White blood cell counts $\left(10^{3} / \mu \mathrm{L}\right)$. $\mathrm{N}=8$ per group.

\begin{tabular}{|l|l|l|l|l|}
\hline & Saline & $\begin{array}{l}\text { Free } \\
\text { docetaxel } \\
(\mathbf{1 0} \mathbf{~ m g} / \mathbf{k g})\end{array}$ & $\begin{array}{l}\mathbf{9 \%}-\mathbf{N P} \\
(\mathbf{1 5} \mathbf{~ m g} / \mathbf{k g})\end{array}$ & $\begin{array}{l}\mathbf{2 0 \%} \mathbf{- N P} \\
(\mathbf{1 5} \mathbf{~ m g / k g})\end{array}$ \\
\hline 1 week before $1^{\text {st }}$ dose & $3.8 \pm 1.1$ & $4.7 \pm 2.0$ & $3.6 \pm 0.8$ & $3.7 \pm 0.8$ \\
\hline 4 days after $1^{\text {st }}$ dose & $3.1 \pm 1.1$ & $2.2 \pm 0.5$ & $1.4 \pm 0.8$ & $1.6 \pm 0.6$ \\
\hline${\text { 4 days after } 6^{\text {th }} \text { dose }}^{\mid}$ & $2.3 \pm 0.6$ & $1.9 \pm 0.6$ & $1.1 \pm 0.3$ & $1.0 \pm 0.4$ \\
\hline
\end{tabular}

